\title{
TWENTY-YEAR FOLLOW-UP OF A Pu/Am INHALATION CASE
}

\author{
C. Wernli* and J. Eikenberg \\ Paul Scherrer Institute (PSI), 5232 Villigen, Switzerland
}

\begin{abstract}
In 1983 a technician inhaled a mixture of Pu/Am aerosols in an accidental situation in the hotlab of Paul Scherrer Institute (PSI). This case is of interest for long-term follow-up since the technician was relatively young (26 y) at the time of intake, no chelating agent was used to alter retention and excretion and the inhaled activity was rather high $(\approx 20 \mathrm{kBq}$ of alpha emitters). The results obtained from periodic lung counts, urinary and faecal excretions as well as from some bone and liver measurements up to the year $\mathbf{2 0 0 3}$ are presented. The measurements were mainly made at PSI but also at FZK Karlsruhe, Germany, and PNNL Hanford, USA. The evaluation and dose estimation of this case was done by several institutions, such as FZK, PNNL and NRPB in addition to PSI. Elements of the case were used in international biokinetic model validation programs by EURADOS/EULEP and IAEA and the ${ }^{241} \mathrm{Am}$ data are given as example in Annex E of the ICRP 'Guide for the Practical Application of the ICRP Human Respiratory Tract Model'. An overview is given on the various results obtained by the different institutions using their models and methods for interpretation of the measured data. While estimation of intake varies by more than an order of magnitude, final estimation of effective committed dose varies only in the range of $0.5-1.5 \mathrm{~Sv}$.
\end{abstract}

\section{THE ACCIDENTAL SITUATION IN 1983}

The former Swiss Federal Institute for Reactor Research (EIR), now Paul Scherrer Institute (PSI) operated a hot lab where research on nuclear fuel has been performed for more than a decade. As a consequence of the production of uranium/plutonium carbide microsphere fuel elements some liquid waste resulted. The volume of this liquid waste was reduced periodically by evaporation in a special apparatus within a glove box of the hot lab. On one occasion an incident happened as described in the original EIR report ${ }^{(1)}$ :

At 16:15 on 24 May 1983 a rapid chemical reaction occurred in an apparatus in which a routine waste sludge evaporation process was under way. The waste was produced during fuel fabrication. The resulting pressure wave ruptured a number of parts at the glove box in which the equipment was situated leading to an alpha contamination of that and neighboring laboratories. The alarm system activated by the fire alarm, the activity detectors and manually by the operators functioned correctly.

A total of seven persons working in the immediate surrounding of the place of the incident inhaled a detectable amount of alpha emitting radionuclides. For one person only the estimated committed dose was above the legal limits. This refers to a young man of $26 \mathrm{y}$ at the time of the incident (M.D., born in 1957). All data on measurements and analysis are given for this person only.

The material dispersed at this incident was a mixture of different waste products in various chemical

${ }^{*}$ Corresponding author: Christian.Wernli@psi.ch forms. Therefore, no detailed information could be given on the chemical form and the particle size distribution of the inhaled radioactive material. The major component of the fuel material used at that time was natural uranium and a plutonium mixture with the badge name $\mathrm{P}-13$. The typical ratio by weight was $\sim 80 \%$ of uranium and $20 \%$ of P-13. The activity of uranium was, therefore, several orders of magnitude lower than for plutonium. The material P-13 has a relative composition as given in Table 1 . This composition was assumed to be applicable for the interpretation of the inhalation case.

Immediately after the incident the most affected person (M.D.) was transferred to the EIR decontamination facility. It turned out that his head and neck were heavily contaminated. A nasal swab and a bronchial slime probe were taken and after a first decontamination a chest count was performed at 19:00 h of May 24. These first measurements gave the following results: nasal swab, $5.5 \mathrm{kBq}$ alpha activity; bronchial slime, $1.4 \mathrm{kBq}$ alpha activity; chest count, $390 \mathrm{~Bq}^{241} \mathrm{Am}$, corresponding to $3.9 \mathrm{kBq}$ alpha activity (for P-13 material).

These results indicated the severity of the inhalation case and the collection of urine and faeces and a follow-up of chest counts was initiated. At that time a decision had also to be taken on the application of a chelating agent to enhance excretion. Ampoules with $\mathrm{Na}$ - and $\mathrm{Ca}-\mathrm{DTPA}$ were available at the EIR decontamination facility for injection. It was assumed that the inhaled $\mathrm{Pu}$ was in an insoluble form and that diethylenetriaminepentacetate (DTPA) would not significantly reduce committed dose, even if it would enhance urinary excretion. Therefore, it was decided not to apply the chelating agents. 
THE MEASUREMENTS PERFORMED ON M.D.

In the 20-y follow-up of this case a total of $>100$ independent measurements were performed at five different laboratories (see Table 2). These measurements consisted of in vivo measurements of the chest, the lungs, the liver, the skeleton and the pulmonary lymph nodes, as well as urinary and faecal analysis. In 1992 a count of chromosomal aberrations in peripheral lymphocytes was also initiated. The results of these measurements are given in the Annexure.

\section{In vivo measurements}

The measurement techniques and the calibration methods for the in vivo measurements have changed dramatically since 1983. The first measurements were taken with phoswich $\mathrm{NaI} / \mathrm{CsI}$-detectors and later on intrinsic germanium detector arrays were used (planar n-type Ge-spectrometers). The three laboratories involved in this type of measurements (Lab 1, 2 and 3) did not directly compare their calibrations in a specific intercomparison exercise. However, all laboratories participated in international intercomparison programs using the Livermore phantom as a reference for chest and lungs. Some effort was made to determine the uncertainty especially of the very early measurements performed at

Table 1. Composition of the fuel material P-13 normalised to total alpha activity.

\begin{tabular}{lcc}
\hline Radionuclide & Alpha activity & Beta activity \\
\hline${ }^{238} \mathrm{Pu}$ & 0.09 & \\
${ }^{239} \mathrm{Pu}$ & 0.55 & \\
${ }^{240} \mathrm{Pu}$ & 0.26 & \\
${ }^{241} \mathrm{Am}$ & 0.10 & 7.50 \\
${ }^{241} \mathrm{Pu}$ & 1.00 & 7.50 \\
Total & & \\
\hline
\end{tabular}

Lab 1. Due to the fact that not all relevant information was completely stored, it was not possible to arrive at a standardised and uniform method for the expression of uncertainty for all these measurements. Therefore, it was decided to present the results without indication of uncertainties.

\section{Urine and faecal analysis}

Prior to the chemical separation procedures to preconcentrate trace levels of $\mathrm{Pu}$ and $\mathrm{Am}$, procedures for sample dissolution are necessary. To destroy the organic matter in urine, Lab 1 added $100 \mathrm{ml} 14 \mathrm{Mol} / 1$ $\mathrm{HNO}_{3}$ to 1 litre samples. After covering with watch glass the solutions were then boiled for about $5 \mathrm{~h}$ until a clear solution was obtained. The faecal samples were initially converted to dry ash in a high temperature oven and the ash was then digested in a glass beaker using a mixture of $\mathrm{HNO}_{3} / \mathrm{H}_{2} \mathrm{SO}_{4}$ under boiling and back-flow via use of a condensation tube. The clear solutions were then taken for radiochemical purification (next paragraph). For chemical yield determination ${ }^{243} \mathrm{Am}$ and ${ }^{242} \mathrm{Pu}$ tracers were added to the urine sample prior to oxidation and to the faecal samples after it was converted to dry ash.

Initially Lab 1 applied a gross alpha method for determination of transuranium isotopes via simultaneous adsorption of actinides on glass fibre materials. This method was later replaced by extraction chromatography methods using selective resins for consecutive separation of $\mathrm{Pu}$ and $\mathrm{Am}$ isotopes. The actinides of the urine samples are pre-concentrated onto a highly selective extractant commercially available as Actinide Resin (EiChrom SA, Darien, IL, USA) simply by adding $200 \mathrm{mg}$ resin to a 0.5 litre sample and stirring for $1 \mathrm{~h}$. The separation of the resin containing the actinides from the bulk of the solution is obtained via filtration on cellulose nitrate membrane filters. Stripping of the reagent from the inert support (polymeric substrate) is performed using organic solvents such as isopropanol. After decomposition on a heating plate the electrolytic

Table 2. Laboratories involved in measurements on the inhalation case of M.D.

\begin{tabular}{lll}
\hline Lab number & \multicolumn{1}{c}{ Name of laboratory } & \multicolumn{1}{c}{ Type of measurements } \\
\hline Lab 1: & $\begin{array}{l}\text { PSI (former EIR), Villigen/Würenlingen, } \\
\text { Switzerland }\end{array}$ & $\begin{array}{l}\text { Chest counts were performed until 1991 with two } \\
\text { phoswich detectors installed in the PSI whole body } \\
\text { counter. Urine and faecal analysis } \\
\text { Chest counts were performed with phoswich detectors } \\
\text { and from 1991 lung, liver, bone and lymph node } \\
\text { measurements were made with Ge detectors. }\end{array}$ \\
Lab 2: & FZK (former KfK), Karlsruhe, Germany & $\begin{array}{l}\text { Urine and faecal analysis } \\
\text { Lung, liver, skeleton and lymph node measurements } \\
\text { were made with Ge detectors }\end{array}$ \\
Lab 4: & PNNL (former PNL), Richland, USA & $\begin{array}{l}\text { Urine analysis } \\
\text { Counting of chromosome aberrations }\end{array}$ \\
\hline
\end{tabular}




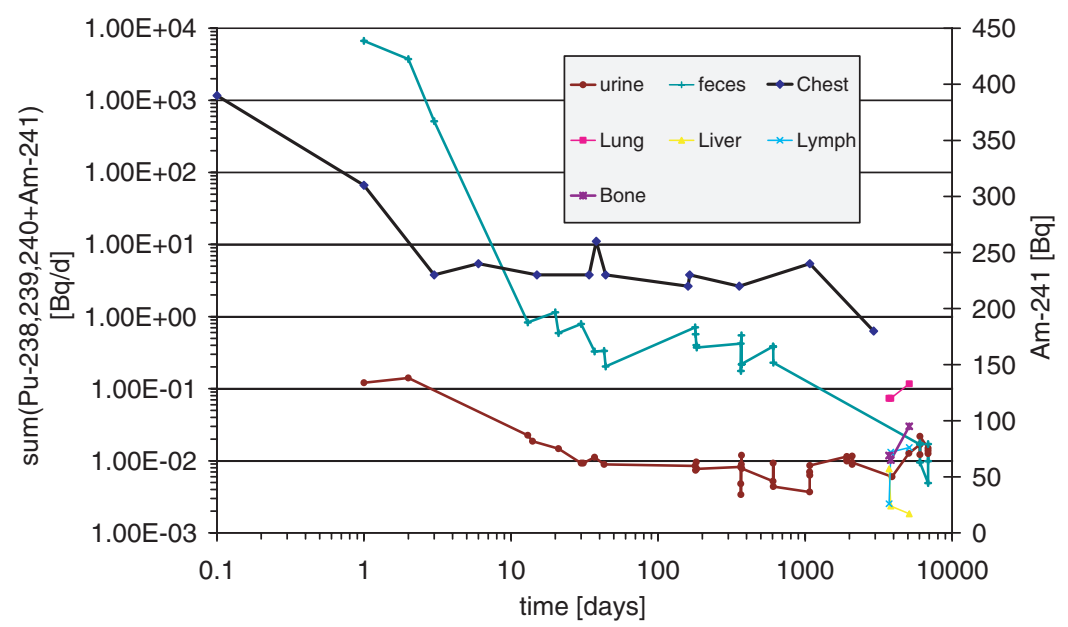

Figure 1. Results of in vivo $\left({ }^{241} \mathrm{Am}\right)$ and excretion $\left({ }^{238,239,240} \mathrm{Pu}\right.$ and $\left.{ }^{241} \mathrm{Am}\right)$ measurements in three different laboratories in the time period of 1983 until 2003.

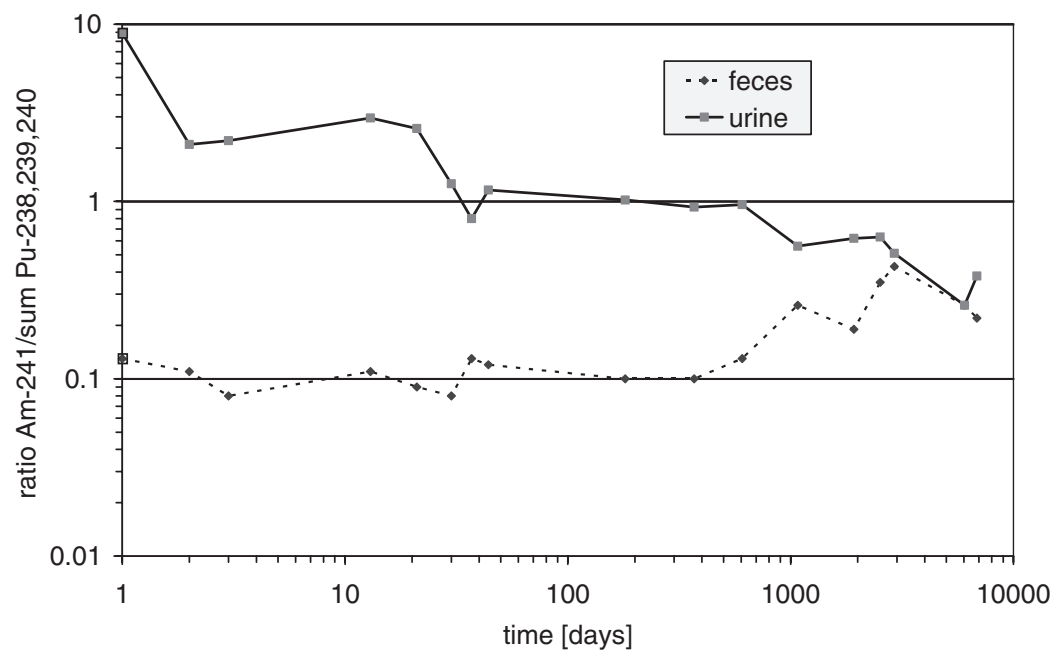

Figure 2. Ratio of americium to alpha emitting plutonium, in excretions of urine and faeces for a time period of $20 \mathrm{y}$ after the inhalation.

deposition is carried out in a $\mathrm{NaHSO}_{4} / \mathrm{H}_{2} \mathrm{SO}_{4}$ buffer solution $^{(2)}$. Chemical separation of the ash samples is carried out using an anion exchanger resin (Biorad AG 1x 2) for isolation of Pu and a TRU-Spec, column (EiChrom) for subsequent extraction of Am. After electrodeposition onto stainless steel plates the $\mathrm{Pu}$ and $\mathrm{Am}$ fractions are analysed by means of high resolution alpha spectrometry ${ }^{(3)}$. For quality control, Lab 1 continuously participated in international intercomparison programs, e.g. organised by the German Federal Department for Public Health or the French 'PROCORAD' program.
The long-term retention of Am in the chest and the excretion of $\mathrm{Pu}$ in urine and faeces are shown in Figure 1. An interesting feature of this case is the time-dependent variation in isotope composition. This is due to two different effects. The inhaled material contained a high initial activity ratio for ${ }^{241} \mathrm{Pu} /{ }^{241} \mathrm{Am}$ of 75 . Since ${ }^{241} \mathrm{Pu}$ has a relatively short half-life of $14.35 \mathrm{y}$ and the decay product is ${ }^{241} \mathrm{Am}$, there is a significant ingrowth of ${ }^{241} \mathrm{Am}$. After $20 \mathrm{y}$ and neglecting excretion the ingrowth of ${ }^{241} \mathrm{Am}$ yielded $\sim 1.5$ times the original amount of the deposited ${ }^{241} \mathrm{Am}$. 
FOLLOW-UP OF A PUIAm INHALATION CASE

Table 3. Evaluation of the inhalation case by different organisations.

\begin{tabular}{|c|c|c|}
\hline Identification & Type of study & Model used \\
\hline EIR, 1983 & First EIR evaluation $^{(4)}$ & ICRP 26, ICRP 30 \\
\hline EIR, 1984 & Second EIR evaluation ${ }^{(5)}$ & ICRP 26, ICRP 30 \\
\hline NRPB, 1992 & Chromosomal analysis on a blood sample $e^{(6)}$ & \\
\hline FZK, 1995 & Comparison of different models ${ }^{(7)}$ & $\begin{array}{l}\text { FZK }{ }^{241} \mathrm{Am} \text { model }^{(8)}, \text { ICRP 26, } \\
\text { IRCP } 60\end{array}$ \\
\hline PNL, 1995 & Comparison of different models ${ }^{(9)}$ & $\begin{array}{l}\text { ICRP } 48, \text { ICRP } 66, \text { ICRP } 67 \\
\text { Tancock } 93^{(10)}\end{array}$ \\
\hline NRPB, 1996 & Evaluation of the inhalation case $e^{(11)}$ & ICRP 66, ICRP 67 \\
\hline IAEA, 1999 & $\begin{array}{l}\text { Intercomparison project }{ }^{(12)} \\
\text { with } 25 \text { participants }\end{array}$ & Various \\
\hline FZK, 2000 & $\begin{array}{l}\text { Intercomparison project } \\
\text { with } 50 \text { participants }\end{array}$ & ICRP 30, ICRP 54, ICRP 66, ICRP 67 \\
\hline FZK, 2002 & Optimisation of ICRP model ${ }^{(14)}$ & ICRP 67 modified \\
\hline ICRP, 2002 & $\begin{array}{l}\text { Application of the ICRP Human Respiratory } \\
\text { Tract Model }{ }^{(15)} \text { with }{ }^{241} \mathrm{Am} \text { data }\end{array}$ & ICRP 30, ICRP 66, ICRP 67 \\
\hline IDEAS, 2005 & Intercomparison project ${ }^{(16)}$ with 35 participants & ICRP 66, ICRP 67 \\
\hline
\end{tabular}

Table 4. Results of the different evaluations.

\begin{tabular}{|c|c|c|c|c|c|c|}
\hline \multirow[t]{2}{*}{ Identification } & \multicolumn{6}{|c|}{ Estimated committed dose (Sv) } \\
\hline & ${ }^{238} \mathrm{Pu}$ & ${ }^{239} \mathrm{Pu}+{ }^{240} \mathrm{Pu}$ & ${ }^{241} \mathrm{Am}$ & Total alpha & ${ }^{241} \mathrm{Pu}$ & Total \\
\hline EIR, 1983 & & & & $0.1-1.2$ & & \\
\hline EIR, 1984 & & & & 1.3 & 0.2 & 1.5 \\
\hline \multicolumn{7}{|l|}{ FZK, 1995} \\
\hline ICRP 26 & 0.74 & & 0.13 & 0.87 & 0.23 & 1.10 \\
\hline IRCP 60 & 0.55 & & 0.09 & 0.64 & 0.15 & 0.79 \\
\hline PNL, 1995 & & & & 0.46 & & \\
\hline NRPB, 1996 & 0.08 & 0.72 & 0.09 & 0.89 & 0.11 & 1.0 \\
\hline \multirow[t]{3}{*}{ IAEA, 1999} & GM: 0.11 & GM: 0.63 & GM: 0.14 & & & \\
\hline & AM: 0.13 & AM: 0.88 & AM: 0.21 & & & \\
\hline & $(0.04-0.3)$ & $(0.2-1.9)$ & $(0.04-0.8)$ & & & \\
\hline \multicolumn{7}{|l|}{ FZK, 2000} \\
\hline ICRP $30+$ & & GM: 0.32 & & & & \\
\hline \multirow[t]{2}{*}{ ICRP 54} & & AM: 0.45 & & & & \\
\hline & & $(0.07-1.4)$ & & & & \\
\hline ICRP $66+$ & & GM: 0.19 & & & & \\
\hline \multirow{2}{*}{ ICRP 67} & & AM: 0.24 & & & & \\
\hline & & $(0.04-0.6)$ & & & & \\
\hline \multirow{6}{*}{$\begin{array}{l}\text { FZK, } 2002 \\
\text { ICRP, } 2002 \\
\text { IDEAS, } 2005\end{array}$} & 0.044 & $0.28+0.13$ & 0.13 & 0.58 & 0.058 & 0.64 \\
\hline & & & 0.06 & & & \\
\hline & & ${ }^{239} \mathrm{Pu}$ only & & & & \\
\hline & & GM: 0.14 & GM: 0.053 & & & \\
\hline & & AM: 0.16 & AM: 0.070 & & & \\
\hline & & $(0.001-1.1)$ & $(0.00006-0.3)$ & & & \\
\hline NRPB, 1992 & Average do & lymphocytes: & & & & \\
\hline
\end{tabular}

GM: Geometric mean. AM: Arithmetic mean of all results of the intercomparison, minimum and maximum in parentheses

In addition early excretions through urine and faeces showed different behaviour. Lung clearance in the early days resulted in a nuclide composition of the faeces equal to the inhaled mix. Otherwise, early urine samples showed a high concentration of ${ }^{241} \mathrm{Am}$ since americium in lungs has a higher excretion rate via urine than plutonium. After several years the excretion is not dominated any more from direct deposition in the lungs and, therefore, the composition of the radionuclide in urine and faeces has changed over time and has become similar as shown in Figure 2. 


\section{WERNLI and J. EIKENBERG}

\section{THE INTERPRETATION OF THE MEASUREMENTS}

This inhalation case has been analysed by quite a number of institutions. The early evaluation had to be done at PSI for reporting to the competent authorities $^{(4,5)}$. Later on the scientific interest in the case came up, especially since retention and excretion were not influenced by chelating agents. The first international study of the case was performed under a CEC contract in the Third Nuclear Fission Framework Programme (1992-1995). In the following years the case was subject of numerous actions as shown in Table 3.

Intake was estimated by different institutions using various models. These estimates varied over more than an order of magnitude. Based on the ICRP Publications 66 and 67 the most probable values are $30-40 \mathrm{kBq}$ of alpha emitting $\mathrm{Pu}$ isotopes and ${ }^{241} \mathrm{Am}$, and $200-300 \mathrm{kBq}{ }^{241} \mathrm{Pu}$. The wide variation of the estimates has shown, that intake is only then a meaningful quantity to characterise the extent of an inhalation case if the model used for intake estimation is given and the same model is used to determine committed dose.

The estimation of committed dose has shown a wide variation among different institutions. The reason for this seems to be the variability of the local application of procedures and methods of dose estimation and not primarily the metabolic and dosimetric models used as such. In the 20 y observation period of this case the recommended internal dosimetry models have changed mainly from ICRP 26/ICRP 30 to ICRP 66/ICRP 67, not to mention the many supporting documents and the various models proposed by individual scientists. Overall, the interpretation and the dose estimation of the case have not changed dramatically with the application of the new models. It is assumed that the effective committed dose $\left(E_{50}\right)$ is in the order of $1 \mathrm{~Sv}$ with an uncertainty of $<0.5 \mathrm{~Sv}$.

\section{CONCLUSIONS AND OUTLOOK}

The $1983 \mathrm{Pu}$ inhalation case has become an important issue for model validation studies and training events in internal dosimetry. It is planned to continue the measurements as long as the subject is willing to participate. Following this overview of the history of the inhalation case a scientific paper on the application of the actual ICRP models will be prepared in collaboration with colleagues from other institutions.

\section{ACKNOWLEDGEMENTS}

The authors express their gratitude to M.D. who suffered the incident in 1983 just before leaving
EIR, and not being involved in any related work since then, for the continuous excellent cooperation for all the measurements that were performed over the past $20 \mathrm{y}$.

\section{REFERENCES}

1. Hausmann, W., Francioni, W., Ingold, F. and Ledergerber, G. Ereignis und Folgen des PuZwischenfalls vom 24.5.83 im Hotlabor. EIR-Bericht Nr. 569 (1985).

2. Bajo, S. and Eikenberg, J. Electrodeposition of actinides for $\alpha$-spectrometry. J. Radioanal. Nucl. Chem. 242, 745-751 (1999).

3. Eikenberg, J., Rüthi, M., Bajo, S., Zumsteg, I., Fern, M. J. and Passo, C. J. Fast radiochemical screening of transuranium nuclides in urine using actinide extractive resin and low level $\alpha / \beta-L S C$. Radioact. Radiochem. 10(3), 19-30 (1999).

4. Wernli, C. Dosisabschätzung zum Zwischenfall vom 24.05.1983 im Hotlabor: Stand Mitte Juni 1983. EIR internal report AN-81-83-10 (Switzerland: EIR) (1983).

5. Wernli, C. Dosisabschätzung zum Zwischenfall vom 24.05.1983 im Hotlabor: Stand Januar 1984. EIR internal report AN-81-84-01 (Switzerland: EIR) (1984).

6. Lloyd, D. Chromosomal analysis on a blood sample from M.D. Private communication, November 21992 (1992).

7. Doerfel, H. Auswertung der Messdaten zum Am/PuInhalationsfall vom 24. Mai 1983. Private communication, May 21995 (1995).

8. Doerfel, H., Beleznay, E. and Beleznay, F. Ein neues biokinetisches Modell zur Beschreibung des Stoffwechsels von Am-241. Tagungsband II, FS-94-71-T, S 26. (FS Jahrestagung, Karlsruhe: Tagungsband) pp. 444-449 (1994).

9. Johnson, J. R. Comparison of measurements from an actinide aerosol exposure case to exponential model results. Private communication, August 141995 (1995).

10. Tancock, N.P. and Taylor, N.A. Derivation of a new expression to describe the urinary excretion of plutonium by man. Radiat. Prot. Dosim. 46(4), 229-239 (1993).

11. Marsh, J. W. and Birchall, A. Intake Assessment of a $\mathrm{Am} / \mathrm{Pu}$ Inhalation in Switzerland on 24 May 1983. Restricted Contract Report NRPB-M732 (Chilton, UK: Health Protection Agency) (1996).

12. International Atomic Energy Agency. Report of a co-ordinated research project. Intercomparison and biokinetic model validation of radionuclide intake assessment. IAEA-TECDOC-1071 (Vienna: IAEA) (1999).

13. Doerfel, H. et al. Third European Exercise on Internal Dose assessment. FZKA 6457 (2000).

14. Luciani, A. Plutonium Biokinetics in Human Body. FZKA 6748 (2002).

15. International Commission on Radiological Protection. Guide for the Practical Application of the ICRP Human Respiratory Tract Model. ICRP Supporting Guidance 3. Ann. ICRP 32, 1-2 (2002).

16. Doerfel $\mathrm{H}$. et al. IAEA/IDEAS intercomparison exercise on internal dose assessment. Radiat. Prot. Dosim. 125(1-4), 52-56 (2007). 
FOLLOW-UP OF A PUIAm INHALATION CASE

ANNEX: RESULTS OF ACTIVITY MEASUREMENTS

Table A1. Chest measurements of ${ }^{241} \mathrm{Am}$.

\begin{tabular}{lcc} 
Laboratory & $\begin{array}{c}\text { Time after } \\
\text { intake (d) }\end{array}$ & $\begin{array}{c}\text { Activity of } \\
{ }^{241} \text { Am (Bq) }\end{array}$ \\
\hline Lab 1 & 0.1 & 390 \\
Lab 1 & 1 & 310 \\
Lab 1 & 3 & 230 \\
Lab 1 & 6 & 240 \\
Lab 1 & 15 & 230 \\
Lab 1 & 34 & 230 \\
Lab 2 & 38 & 260 \\
Lab 1 & 44 & 230 \\
Lab 1 & 160 & 220 \\
Lab 2 & 164 & 230 \\
Lab 1 & 357 & 220 \\
Lab 1 & 1077 & 240 \\
Lab 1 & 2925 & 180 \\
\hline
\end{tabular}

The ${ }^{241}$ Am detected in the chest measurements at later times results from ${ }^{241} \mathrm{Am}$ located in the lung, the pulmonary lymph nodes and the ribs of the subject.

Table A2. Activity of ${ }^{241} \mathrm{Am}$ in lung, liver, lymph and bone.

\begin{tabular}{llcc}
\hline Laboratory & Organ & $\begin{array}{c}\text { Time after } \\
\text { intake (d) }\end{array}$ & $\begin{array}{c}\text { Activity of } \\
\text { 241 Am (Bq) }\end{array}$ \\
\hline Lab 3 & Lung & 3724 & 120 \\
Lab 2 & Lung & 3828 & 120 \\
Lab 2 & Lung & 5110 & 133 \\
Lab 3 & Liver & 3724 & 57 \\
Lab 2 & Liver & 3828 & 24 \\
Lab 2 & Liver & 5110 & 17 \\
Lab 3 & Lymph & 3724 & 26 \\
Lab 2 & Lymph & 3828 & 72 \\
Lab 2 & Lymph & 5110 & 76 \\
Lab 3 & Bone & 3724 & 69 \\
Lab 2 & Bone & 3828 & 65 \\
Lab 2 & Bone & 5110 & 95 \\
\hline
\end{tabular}

Table A3. Excretion in urine.

\begin{tabular}{cccc}
\hline Lab & $\begin{array}{c}\text { Time after } \\
\text { intake }(\mathrm{d})\end{array}$ & $\begin{array}{c}{ }^{239} \mathrm{Pu}+{ }^{240} \mathrm{Pu} \\
{[\mathrm{mBq} / \mathrm{d}]}\end{array}$ & $\begin{array}{c}{ }^{241} \mathrm{Am}+{ }^{238} \mathrm{Pu} \\
{[\mathrm{mBq} / \mathrm{d}]}\end{array}$ \\
\hline Lab 1 & 1 & 11 & 110 \\
Lab 1 & 2 & 41 & 100 \\
Lab 1 & 13 & 6 & 17 \\
Lab 1 & 14 & 4 & 15 \\
Lab 1 & 21 & 4 & 11 \\
\hline
\end{tabular}

Table A3. Continued

\begin{tabular}{|c|c|c|c|}
\hline $\mathrm{Lab}$ & $\begin{array}{l}\text { Time after } \\
\text { intake }(d)\end{array}$ & $\begin{array}{c}{ }^{239} \mathrm{Pu}+{ }^{240} \mathrm{Pu} \\
{[\mathrm{mBq} / \mathrm{d}]}\end{array}$ & $\begin{array}{c}{ }^{241} \mathrm{Am}+{ }^{238} \mathrm{Pu} \\
{[\mathrm{mBq} / \mathrm{d}]}\end{array}$ \\
\hline Lab 1 & 30 & 4 & 6 \\
\hline Lab 1 & 31 & 4 & 6 \\
\hline Lab 1 & 37 & 6 & 6 \\
\hline Lab 1 & 180 & 3 & 4 \\
\hline Lab 1 & 43 & 4 & 5 \\
\hline Lab 1 & 179 & 5 & 4 \\
\hline Lab 1 & 180 & 3 & 4 \\
\hline Lab 1 & 182 & 4 & 6 \\
\hline Lab 1 & 183 & 3 & 4 \\
\hline Lab 1 & 364 & 5 & 4 \\
\hline Lab 1 & 365 & 2 & 3 \\
\hline Lab 1 & 366 & 2 & 2 \\
\hline Lab 1 & 369 & 4 & 5 \\
\hline Lab 1 & 370 & 5 & 7 \\
\hline Lab 1 & 371 & 4 & 4 \\
\hline Lab 1 & 605 & 3 & 3 \\
\hline Lab 1 & 606 & 4 & 5 \\
\hline Lab 1 & 607 & 2 & 2 \\
\hline Lab 1 & 1074 & 2 & 2 \\
\hline Lab 1 & 1075 & 4 & 3 \\
\hline Lab 1 & 1076 & 3 & 3 \\
\hline Lab 1 & 1077 & 6 & 3 \\
\hline Lab 1 & 1921 & 6 & 6 \\
\hline Lab 1 & 1922 & 5 & 5 \\
\hline Lab 1 & 1923 & 7 & 4 \\
\hline Lab 1 & 2089 & 7 & 5 \\
\hline Lab 1 & 2090 & 5 & 4 \\
\hline Lab 1 & 2091 & 7 & 3 \\
\hline Lab 1 & 3902 & 3 & 3 \\
\hline Lab 1 & 5076 & 9 & 4 \\
\hline Lab 2 & 6043 & 11 & 6 \\
\hline Lab 2 & 6044 & 10 & 3 \\
\hline Lab 2 & 6045 & 16 & 6 \\
\hline Lab 1 & 6859 & 10 & 6 \\
\hline Lab 1 & 6860 & 10 & 4 \\
\hline \multirow[t]{3}{*}{ Lab 1} & 6870 & 9 & 4 \\
\hline & & ${ }^{238,239,240} \mathrm{Pu}$ & ${ }^{241} \mathrm{Am}$ \\
\hline & & {$[\mathrm{mBq} / \mathrm{d}]$} & {$[\mathrm{mBq} / \mathrm{d}]$} \\
\hline Lab 1 & 2092 & & 2 \\
\hline Lab 1 & 2095 & & 4 \\
\hline Lab 2 & 2525 & 4 & $<1.5$ \\
\hline Lab 2 & 2526 & 6 & 5 \\
\hline Lab 2 & 2527 & 7 & 3 \\
\hline Lab 2 & 2921 & 5 & 3 \\
\hline Lab 2 & 2922 & 4 & 2 \\
\hline Lab 2 & 2923 & $<1.5$ & $<1.5$ \\
\hline Lab 3 & 3723 & 10 & \\
\hline Lab 3 & 3725 & 9 & \\
\hline Lab 2 & 6043 & 13 & 5 \\
\hline Lab 2 & 6044 & 10 & 2 \\
\hline Lab 2 & 6045 & 17 & 5 \\
\hline Lab 1 & 6859 & 10 & 5 \\
\hline Lab 1 & 6860 & 10 & 3 \\
\hline Lab 1 & 6861 & 9 & 3 \\
\hline
\end{tabular}


Table A4. Excretion in feces.

\begin{tabular}{|c|c|c|c|c|c|c|}
\hline \multirow{2}{*}{ Lab } & \multirow{2}{*}{$\begin{array}{l}\text { Time after } \\
\text { intake }(d)\end{array}$} & \multirow{2}{*}{$\begin{array}{c}{ }^{239} \mathrm{Pu}+{ }^{240} \mathrm{Pu} \\
{[\mathrm{mBq} / \mathrm{d}]}\end{array}$} & \multirow{2}{*}{$\begin{array}{c}{ }^{241} \mathrm{Am}+{ }^{238} \mathrm{Pu} \\
\mathrm{mBq} / \mathrm{d}]\end{array}$} & \multirow{4}{*}{ Days } & & \\
\hline & & & & & \multicolumn{2}{|c|}{$\underset{\left({ }^{238} \mathrm{Pu}+{ }^{239} \mathrm{Pu}+{ }^{240} \mathrm{Pu}\right)}{{ }^{241} \mathrm{Am} /}$} \\
\hline Lab 1 & 1 & 5200000 & 1500000 & & & \\
\hline Lab 1 & 2 & 3000000 & 740000 & & Feces & Urine \\
\hline Lab 1 & 3 & 440000 & 74000 & & & \\
\hline \multirow{2}{*}{$\begin{array}{l}\text { Lab } 1 \\
\text { Lab } 1\end{array}$} & 13 & 670 & 160 & 1 & 0.13 & 8.9 \\
\hline & 20 & 960 & 190 & 2 & 0.11 & 2.1 \\
\hline \multirow{2}{*}{$\begin{array}{l}\text { Lab } 1 \\
\text { Lab } 1\end{array}$} & 21 & 480 & 110 & 3 & 0.08 & \\
\hline & 30 & 670 & 120 & 13 & 0.11 & 2.96 \\
\hline \multirow{2}{*}{$\begin{array}{l}\text { Lab } 1 \\
\text { Lab } 1\end{array}$} & 37 & 250 & 78 & 21 & 0.09 & 2.58 \\
\hline & 43 & 260 & 74 & 30 & 0.08 & 1.26 \\
\hline Lab 1 & 44 & 160 & 44 & 37 & 0.13 & 0.80 \\
\hline Lab 1 & 179 & 590 & 120 & 44 & 0.12 & 1.16 \\
\hline Lab 1 & 180 & 470 & 100 & 181 & 0.10 & 1.02 \\
\hline \multirow{2}{*}{$\begin{array}{l}\text { Lab } 1 \\
\text { Lab } 1\end{array}$} & 182 & 310 & 93 & 369 & 0.10 & 0.93 \\
\hline & 183 & 310 & 63 & 606 & 0.13 & 0.96 \\
\hline Lab 1 & 365 & 340 & 81 & 1076 & 0.26 & 0.56 \\
\hline Lab 1 & 366 & 150 & 26 & 1922 & 0.19 & 0.62 \\
\hline Lab 1 & 369 & 440 & 110 & 2526 & 0.35 & 0.63 \\
\hline Lab 1 & 370 & 180 & 37 & 2922 & 0.43 & 0.51 \\
\hline Lab 1 & 371 & 180 & 41 & 6044 & 0.26 & 0.26 \\
\hline Lab 1 & 605 & 300 & 85 & 6860 & 0.22 & 0.38 \\
\hline Lab 1 & 606 & 300 & 80 & & & \\
\hline Lab 1 & 607 & 170 & 59 & & & \\
\hline Lab 2 & 6043 & 12 & 5 & & & \\
\hline Lab 2 & 6044 & 13 & 5 & & & \\
\hline Lab 2 & 6045 & 8 & 2 & & & \\
\hline Lab 1 & 6859 & 4 & 1 & & & \\
\hline Lab 1 & 6860 & 14 & 3 & & & \\
\hline Lab 1 & 6861 & 7 & 3 & & & \\
\hline & & ${ }^{238,239,240} \mathrm{Pu}$ & ${ }^{241} \mathrm{Am}$ & & & \\
\hline & & [mBq/d] & {$[\mathrm{mBq} / \mathrm{d}]$} & & & \\
\hline Lab 1 & 1074 & 70 & 18 & & & \\
\hline Lab 1 & 1075 & 120 & 30 & & & \\
\hline Lab 1 & 1076 & 65 & 17 & & & \\
\hline Lab 1 & 1077 & 25 & 7 & & & \\
\hline Lab 1 & 1921 & 90 & 13 & & & \\
\hline Lab 1 & 1922 & 190 & 46 & & & \\
\hline Lab 1 & 1923 & 100 & 15 & & & \\
\hline Lab 2 & 2525 & 47 & 17 & & & \\
\hline Lab 2 & 2526 & 17 & 5 & & & \\
\hline Lab 2 & 2527 & 38 & 13 & & & \\
\hline Lab 2 & 2921 & 5 & $<1.5$ & & & \\
\hline Lab 2 & 2922 & 13 & 6 & & & \\
\hline Lab 2 & 2923 & 3 & $<1.5$ & & & \\
\hline Lab 3 & 3723 & 15 & & & & \\
\hline Lab 3 & 3725 & 11 & & & & \\
\hline Lab 2 & 6043 & 13 & 4 & & & \\
\hline Lab 2 & 6044 & 14 & 4 & & & \\
\hline Lab 2 & 6045 & 9 & 2 & & & \\
\hline Lab 1 & 6859 & 4 & 1 & & & \\
\hline Lab 1 & 6860 & 14 & 2 & & & \\
\hline Lab 1 & 6861 & 8 & 2 & & & \\
\hline
\end{tabular}

Table A5. Ratio of americium to total $\alpha$-emitting plutonium in feces and urine. 